\title{
MENINGKATKAN HASIL BELAJAR DENGAN MENGGUNAKAN MEDIA CHARTA UNTUK MATERI SISTEM PENCERNAAN PADA MANUSIA KELAS VIIIA MTSN 2 WAY KANAN
}

\author{
Akbar Setia \\ akbarsetia81@gmail.com
}

Staf Pengajar MTsN 2 Way Kanan

\begin{abstract}
Abstrak : Inggris. This research is aims to improve the results of learning students on the material of human digestive system. This research is a study the class composed of three cycle where every cycle covering the 4 stage nemely :planning, action, observation, and reflektion. The object research is the VIIIA MTSN 2 Way Kanan. The data taken in the form of the results of the competency test a well the sheets observations during the learning. From the analysis that the results of learning student increased significantly. This be seen from teh completeness studens from the results of the competency test on 30 student on VIIIA, the students completely learned as musch 50\%(15 students) at the first cycle, then in the second cycle make 75\%(20 students) while in the third cycle 80\%(24 student).
\end{abstract}

Keywords: The result of learning, Digestive system, Charta media.

Abstrak : Indonesia. Penelitian ini bertujuan guna meningkatkan hasil belajar siswa pada materi sistem pencernaan manusia. Penelitian ini merupakan penelitian tindakan kelas tersusun atas tiga siklus dimana per siklus meliputi 4 tahap yakni planning (perencanaan), aktion( tindakan), observation(pengamatan dan reflection(refleksi). Objek penelitian siswa kelas VIIIA MTsN 2 Way Kanan. Data yang diambil berupa hasil uji kompetensi serta lembar observasi selama kegiatan belajar. Dari analisis diperoleh bahwa hasil belajar siswa mengalami kenaikan signifikan. Ini dilihat dari ketuntasan siswa dari hasil uji kompetensi terhadap 30 siswa kelas VIIIA, yakni siswa tuntas belajar sebanyak $50 \%$ (15 siswa) pada siklus pertama, kemudian di siklus kedua menjadi 75\%(20 siswa) sedangkan pada siklus ketiga 80\%(24 siswa).

Kata Kunci : Hasil belajar, Sistem Pencernaan, Media charta

\section{PENDAHULUAN}

\section{a. Latar Belakang}

Salah satu ilmu yang mendukung perkembangan teknologi adalah pelajaran IPA. Hal ini yang membuat pengetahuan IPA selalu update dengan perkembangan teknologi. Oleh karena itu penting bagi guru IPA mampu mengajar dengan baik, menguasai kelas serta materi pelajaran yang akan disampaikan.
Kemampuan guru yang minimal dapat membuat siswa kurang berminat dengan pelajaran IPA. Karena akan terkesan bahwa IPA adalah pelajaran yang sulit. Oleh karena itu diperlukan pendekatan-pendekatan dalam mengajar IPA. Pendekatan yang konvensional dirasa masih belum maksimal untuk menaikkan hasil belajar pelajaran IPA.

Tidak sedikit siswa yang kurang menyukai mata pelajaran IPA, karena siswa kebanyakan memandang pelajaran IPA 
merupakan pelajaran yag sukar untuk dipahami. Hal ini diseabka dari guru atau siswa itu sendiri. Tingkat kesukaran inilah yang mungkin menjadi kegelisahan siswa ketika mata pelajaran IPA berlangsung. Selain itu, faktor yang dapat membuat siswa sulit memahami pelajaran IPA adalah ketidaktepatan pendidik dalam melakukan pendekatan, termasuk dengan pemilihan metode dalam mengajar.

Pemilihan metode yang kurang tepat inilah yang mengakibatkan hasil evaluasi belajar siswa, khususnya mata pelajaran IPA, seringkali muncul adalah nilai yang kecil dan tidak memuaskan. Tentu saja hal ini bisa disebabkan banyak faktor, bisa dari siswa itu sendiri atau dari guru sebagai pendidik yang kurang kreativitas dalam mengajar dikelas.

Oleh karena itu, penting bagi guru melakukan upaya-upaya yang dapat memicu gairah siswa dalam belajar IPA, hal ini memungkikan akan memotivasi siswa dalam belajar. Siswa yang giat dalam belajar karena tertarik dengan kreativitas guru sangat memungkinkan akan menghasilkan nilai vealuasi yang memuaskan. Pendekatan konvensioal yang sudah biasa dilakukan guru dalam mengajar IPA dikelas hendaknya mencoba dengan metode lain dalam memberikan pembelajaran dikelas. Karena justru pendekatan inilah yang memang diperlukan siswa dalam menyerap ilmu yang ditransfer oleh guru dalam pembelajaran di kelas.
Sering kita jumpai hasil belajar siswa yang kurang sesuai dengan apa yang kita harapkan. Hal ini dapat disebabkan karena memang materi pelajaran yang cukup rumit atau gairah belajar siswa yang sedang menurun.

Seorang pendidik sudah menjadi sebuah kebaikan apabila melakukan upaya-upaya untuk meningkatkan hasil belajar siswa, termasuk siswa yang sedang lemah semangat belajarnya. Mengjadapi hal ini, tentu penting bagi pendidik berbenah diri dalam menyampaikan materi belajar selama ini. Bisa jadi metode mengajarnya yang perlu dirubah. Bisa saja ketika menemukan materi yang cukup rumit dalam memberikan materi pelajaran. Tetapi metode atau cara mengajarnya tetap menggunakan cara konvensional dalam melaksanaan pembelajaran dikelas. Hal ini, tentu tidak akan berdampak banyak terhadap kondisi siswa yang sedang lemah dalam belajarnya.

Dalam situasi dan kondisi seperti ini, tentunya seorang pendidik perlu melakukan upaya yang dapat membangkitkan semangat belajar siswa, termasuk dengan merubah cara mengajar konvensional yang selama ini sudah dilakukan.

Diperlukan strategi untuk memudahkan daya serap siswa terhadap meteri pelajaran yang rumit. Selain itu diperlukan pendekatanpendekatan dalam memiih metode dalam pembelajaran di kelas. Penggunaan metode yang tepat akan membuat siswa termotivasi 
dalam belajar mata pelajaran IPA. Ketika siswa sudah termotivasi dalam belajar maka pembelajaran dikelas akan berjalan baik dan sangat memugkinkan memperoleh hasil yang baik pula.

Untuk menaikkan hasil belajar siswa, selain pendekatan konvensional. Seorang guru dapat mencari ide cemerlang dan brilian yang dapat membuat suasana belajar nyaman dan siswa akan aktiv dalam mengikuti pelajaran.

Salah satu ide sebagai alat bantu untuk membuat siswa senang dalam belajar adalah dengan membuat media charta.

Menurut Makuda dan Russel, 90 sampai 95 persen waktu belajar hendaknya dilakukan dengan media pembelajaran, adanya kesesuaian antara materi yang diajarkan dengan media membantu siswa secara efektif dalam belajar.

Fungsi media pembelajaran menurut Hermawan :

1) Sebagai sarana bantu untuk mewujudkan situasi belajar mengajar yang efektif.

2) Sebagai bahan integral dari keseluruhan proses pembelajaran.

3) Untuk mempercepat proses belajar dalam arti siswa lebih mudah dan lebih cepat menangkap tujuan dan bahann ajar.

4) Untuk meningkatkan kualitas proses belajar mengajar.

Penggunaan media charta akan membuat penyajian lebih menarik dan perpotensi untuk meningkatkan minat belajar siswa. Sehingga dimungkinkan ini dapat meningkatnya nilai mata pelajaran IPA.

Memberikan materi pelajaran dengan menggunakan media charta akan meningkatkan semangat belajar siswa dalam mengikuti pembelajaran dikelas dan siswa akan lebih siap dalam menghadapi evalusi yang akan diberikan oleh guru saat melakukan penilaian terhadap hasil belajar siswa.

\section{b. Rumusan Masalah}

Yang jadi rumusan masalah adalah; Apakah dengan menggunakan media charta bisa meningkatkan nilai hasil belajar siswa untuk materi sistem pencernaan manusia kelas VIIIA MTsN 2 Way Kanan?

\section{c. Tujuan Penelitian}

Penelitian ini memiliki tujuan untuk mengetahui kenaikan nilai hasil belajar siswa yang menggunakan media charta di kelas VIIIA MTsN 2 Way Kanan.

\section{d. Manfaat Penelitian}

Manfaat penelitian adalah sebagai berikut;

1. Dapat menaikkan nilai hasil belajar siswa khusunya kelas VIIIA MTsN 2 Way Kanan.

2. Hasil penelitian ini bisa digunakan sebagai bahan pertimbangan bagi pendidik untuk 
memilih media pembe-lajaran mengajar dikelas.

3. Sebagai informasi untuk masyarakat secara umum.

4. Sebagai sumber belajar untuk perpustakaan.

5. Meningkatkan pemahaman penulis dalam materi sistem percernaan pada manusia.

\section{METODE PENELITIAN}

\section{a. Waktu, dan Tempat}

Penelitian dikerjakan selama 4 bulan dimulai bulan September 2019 sampai Desember 2019. Bertempat di MTsN 2 Way Kanan, yakni pada kelas VIIIA semester ganjil di tahun pelajaran 2019/2020.

\section{b. Pelaksanaan pada Siklus Pertama} (Siklus I)

Untuk siklus pertama penelitian dilaksanakan selama dua pekan yaitu pada minggu pertama dan pekan kedua pada bulan September 2019. Pada minggu kedua juga diakhiri dengan melakukan evaluasi hasil belajar siswa untuk siklus pertama.

Dalam pelaksanaan proses pembelajaran di siklus pertama guru menerapkan pembelajaran dengan menggunakan media charta dengan kompetensi dasar materi adalah sistem pencernaan untuk manusia serta hubungan dengan kesehatan tubuh.
Untuk maksud pembelajaran adalah; pertama, murid dapat menjabarkan macam makanan apa saja yang dibutuhkan tubuh manusia. Kedua, murid dapat mendeskripsikan sistem pencernaan pada manusia dan hubungannya dengan kesehatan.

Setelah pasca kegiatan pembelajaran evalusi dilakukan guna mengetahui sejauh mana pemahaman murid dengan materi sistem pencernaan manusia dan hubungan dengan kesehatan tubuh.

\section{c. Pelaksanaan pada Siklus Kedua (Siklus 2)}

Sama halnya siklus pertama, pada siklus kedua penelitian dilakukan selama 2 minggu, yakni minggu ketiga dan minggu ke empat pada bulan Oktober 2019. Pada minggu keempat diakhiri dengan melakukan evaluasi hasil belajar siswa untuk siklus kedua.

Dalam pelaksanaan proses pembelajaran di siklus kedua guru menerapkan kegiatan pembelajaran menggunakan media charta dengan kemampuan dasar-dasar materi sistem pencernaan di manusia dan hubungan dengan kesehatan tubuh.

Untuk tujuan pembelajaran adalah; pertama, siswa dapat menjelaskan perbedaan antara pencernaan mekanik dan kimia serta manfaatnya bagi tubuh. Kedua, siswa dapat menjelaskan penyakit apa saja yang terdapat pada sistem pencernaan manusia. 


\section{d. Pelaksanaan pada Siklus Ketiga} (Siklus 3)

Sama halnya siklus pertama dan siklus kedua, pada siklus ketiga penelitian dilakukan selama 2 minggu, yakni minggu pertama dan minggu ke dua pada bulan November 2019. Pada minggu kedua di-akhiri dengan melakukan evaluasi hasil be-lajar siswa untuk siklus ketiga.

Dalam pelaksanaan proses pembelajaran di siklus ketiga guru menerapkan pembelajaran dengan menggunakan media charta dengan kemampuan dasar materi adalah sistem pencernaan manusia dan hubungannya dengan kesehatan tubuh.

Untuk tujuan belajarnya yaitu; pertama, siswa dapat menjelaskan organ-organ penyusun sistem pencernaan manusia. Kedua, murid bisa menjabarkan fungsi organ yang menyusun sistem pencernaan manusia.

\section{d. Objek dan Subjek Penelitian}

Digunakan sebagai subjek penelitian tindakan kelas yaitu siswa kelas VIIIA MTsN 2 Way Kanan pada di semester gasal tahun pelajaran 2019/2020 yang berjumlah 30 siswa. Yakni 17 siswa berjenis kelamin perempuan dan 13 siswa berjenis kelamin laki-laki.

Objek dalam pelaksanaan penelitian adalah pembelajaran dikelas dengan media charta.

\section{e. Perbaikan Pembelajaran}

Perbaikan pembelajaran dilakukan melalui proses pengkajian berdaur yang terdiri dari 4 tahap, yaitu:

1) Merencanakan(planning)

2) Pelaksanaan(acting)

3) Observasi(observating)

4) Refleksi(reflecting)

Tahapan perbaikan menurut I. G. A. K Wardani(2006) seperti di sajikan dalam bagan berikut ini;

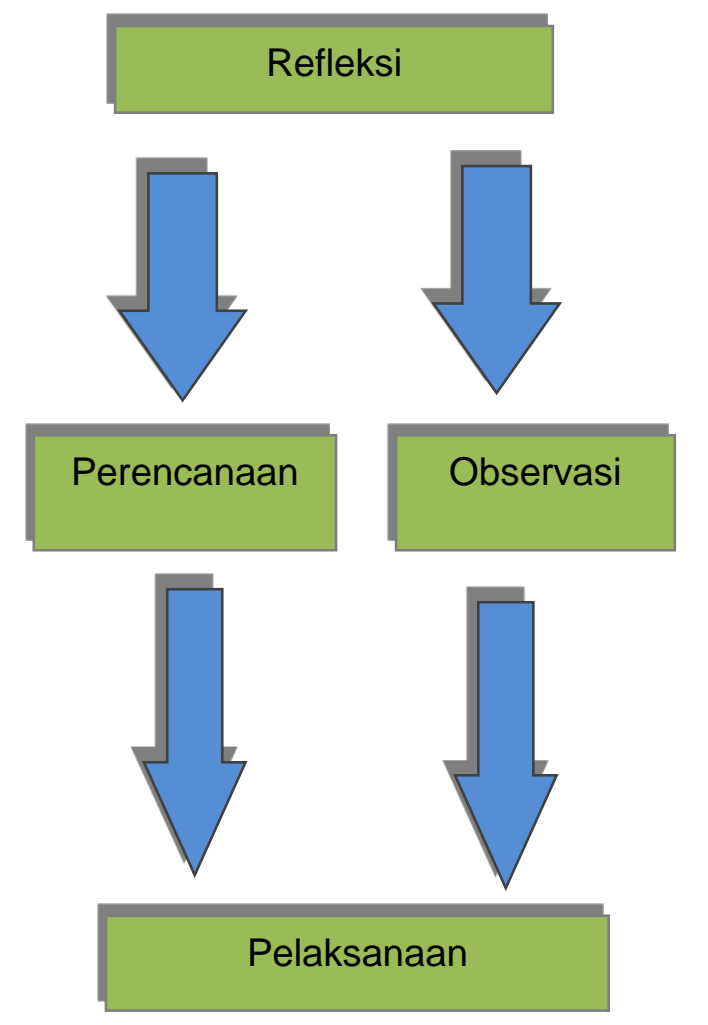

Gambar. Tahap PTK I. G. A. K Wardani (2006)

\section{HASIL DAN PEMBAHASAN}

a. Hasil

\section{Siklus Pertama (Siklus I)}

Hasil penelitian siklus pertama adalah seperti dalam tabel berikut; 
Tabel I.

Rekaputilasi Hasil Evaluasi Kompetensi Siklus Pertama.

\begin{tabular}{|c|c|c|c|}
\hline No & $\begin{array}{c}\text { Instrumen } \\
\text { Kegiatan }\end{array}$ & Hasil \\
\hline 1 & Nilai rata-rata siswa & & 76,00 \\
\hline 2 & Siswa tuntas belajar & & 15 \\
\hline 3 & $\begin{array}{c}\text { Persentase } \\
\text { Ketuntasan }\end{array}$ & $50 \%$ \\
\hline
\end{tabular}

Dari tabel I. Dengan mengajar dengan menggunakan media charta pada kelas VIIIA MTsN 2 Way Kanan pada siklus pertama diperoleh hasil evaluasi siswa rata-ratanya 76,00 dan untuk ketuntasanya mencapai angka 50\%, artinya dari 30 siswa kelas VIIIA 15 siswa sudah tuntas belajar. Hal ini karena nilai KKM yang digunakan adalah 70 . Dan ada 15 siswa yang perolehan nilainya diatas 70 .

\section{Siklus Kedua(Siklus II)}

Hasil penelitian siklus kedua adalah seperti dalam tabel berikut;

Tabel 2. Rekaputilasi Hasil Evaluasi

Kompetensi Siklus Pertama.

\begin{tabular}{|c|c|c|}
\hline No & Instrumen Kegiatan & Hasil \\
\hline 1 & Nilai rata-rata siswa & 80,00 \\
\hline 2 & Siswa tuntas belajar & 20 \\
\hline 3 & Persentase Ketuntasan & $75 \%$ \\
\hline
\end{tabular}

Dari tabel 2. Dengan mengajar menggunakan media charta pada kelas VIIIA
MTsN 2 Way Kanan pada siklus kedua diperoleh hasil evaluasi siswa rata-ratanya 80,00 dan untuk ketuntasanya mencapai angka $75 \%$, artinya dari 30 siswa kelas VIIIA 20 siswa sudah tuntas belajar. Ini karena nilai KKM yang digunakan adalah 70. Dan ada 20 siswa yang perolehan nilainya diatas 70 .

Pada siklus sudah terjadi peningkat hasil belajar siswa, dimana ketuntasan belajar siswa sesuai KKM yang pada siklus pertama berjumlah 15 siswa, terjadi peningkatan $25 \%$, sehingga pada siklus kedua siswa yang tuntas belajar menjadi 20 siswa atau $75 \%$. Untuk lebih jelasnya dapat diamati pada tabel 1 dan tabel 2.

\section{Siklus Ketiga (Siklus III)}

Tabel 3. Rekaputilasi Hasil Evaluasi Kompetensi Siklus Ketiga.

\begin{tabular}{|l|l|l|}
\hline No & Instrumen Kegiatan & Hasil \\
\hline 1 & Nilai rata-rata siswa & 86,00 \\
\hline 2 & Siswa tuntas belajar & 24 \\
\hline 3 & Persentase Ketuntasan & $80 \%$ \\
\hline
\end{tabular}

Dari tabel 3. Dengan mengajar dengan menggunakan media charta pada kelas VIIIA MTsN 2 Way Kanan pada siklus kedua diperoleh hasil evaluasi siswa rata-ratanya 86,00 dan untuk ketuntasanya mencapai angka $80 \%$, artinya dari 30 siswa kelas VIIIA 24 siswa sudah tuntas belajar. Hal ini karena nilai KKM yang digunakan adalah 70. Dan 
ada 24 siswa yang perolehan nilainya diatas 70.

Pada siklus ketiga ketuntasan belajar siswa terjadi peningkatan dibanding dengan siklus kedua. Pada siklus kedua, siswa yang tuntas belajar standar KKM ada 20 siswa, dan pada siklus ketiga, siswa yang tuntas belajar sesuai KKM ada 24 siswa. Artinya, pada siklus ketiga terjadi peningkatan sebesar $5 \%$ dibanding dengan siklus kedua. Sehingga ketuntasan belajar siswa pada siklus 3 menjadi $80 \%$. Untuk lebih jelasnya bisa diamati pada tabel 2 dan tabel 3.

\section{Pembahasan}

Hasil penelitian tindakan kelas dengan melakukan kegiatan pembelajaran menggunakan media charta dapat berdampak positif untuk meningkatkan hasil belajar siswa. Ini bisa diketahui meningkatnya hasil belajar siswa dan ketuntasan belajar siswa.

Dari siklus pertama (I), siklus kedua (II) dan siklus ketiga (III) terjadi signifikasi peningkatan dari hasil rata rata evalusi siswa yang dilaksanakan setelah kegiatan pembelajaran.

Pada siklus pertama ketuntasan siswa belajar dapat dilihat dari hasil evaluasi belajar siswa yakni $50 \%$ siswa yang tuntas belajar. Sedangkan pada siklus kedia, terjadi peningkatan menjadi $75 \%$ siswa tuntas belajar dan pada siklus terakhir atau siklus ketiga ketuntasan belajar siswa mencapai $80 \%$. Hal ini dikarenakan kegiatan belajar mengajar dengan menggunakan media charta dapat memicu gairah belajar siswa sehingga siswa semangat dalam mengikuti materi pelajaran IPA.

Bisa kita lihat kenaikan nilai rata-rata siswa, dimana rata-rata nilai pada siklus pertama adalah 76, dan pada siklus kedua nilai rata-rata siswa meningkat menjadi 80 , dan terus meningkat disiklus ketiga menjadi 86.

Untuk lebih jelasnya bisa dilihat dalam grafik berikut;

Grafik I. Nilai rata-rata hasil siswa siklus pertama I, siklus kedua/II dan siklus ketiga

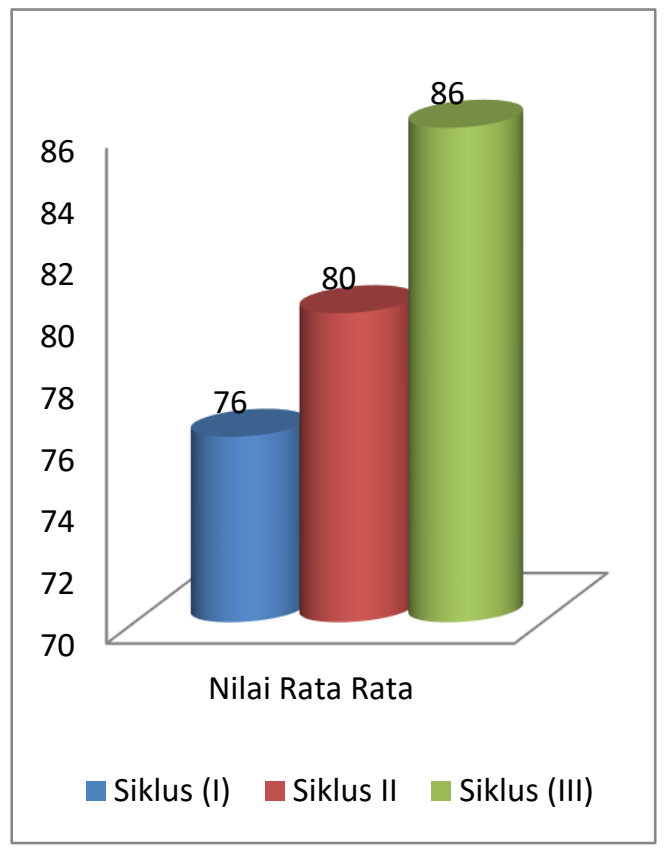

Dari grafik diatas, terjadi peningkatan nilai rerata siswa dimana nilai rata-rata siswa 76,00 pada siklus pertama, kemudian terjadi peningkatan pada siklus kedua/II menjadi 80,00 dan pada siklus ketiga/III menjadi 86,00 . 
Ini merupakan hasil belajar yang belajar, kemudian untuk siklus kedua diharapkan pendidik, oleh karena itu melak- meningkat menjadi 20 siswa yang sudah sanakan kegiatan pembelajaran dikelas de- tuntas belajar atau 75\% kemudian pada siklus ngan menggunakan media charta akan ber- ketiga jumlah siswa yang tuntas atau khatam dampak positif untuk meningkatkan hasil be- belajar mencapai 24 siswa atau $80 \%$. lajar siswa.

Angka $80 \%$ siswa yang tutas belajar

Dalam hal ketuntasan belajar, juga terjadi peningkatan cukup signifikan, untuk lebih jelasnya dilihat di grafik 2.

Grafik 2. Ketuntasan belajar siswa pada siklus pertama/I siklus kedua/II dan siklus ketiga

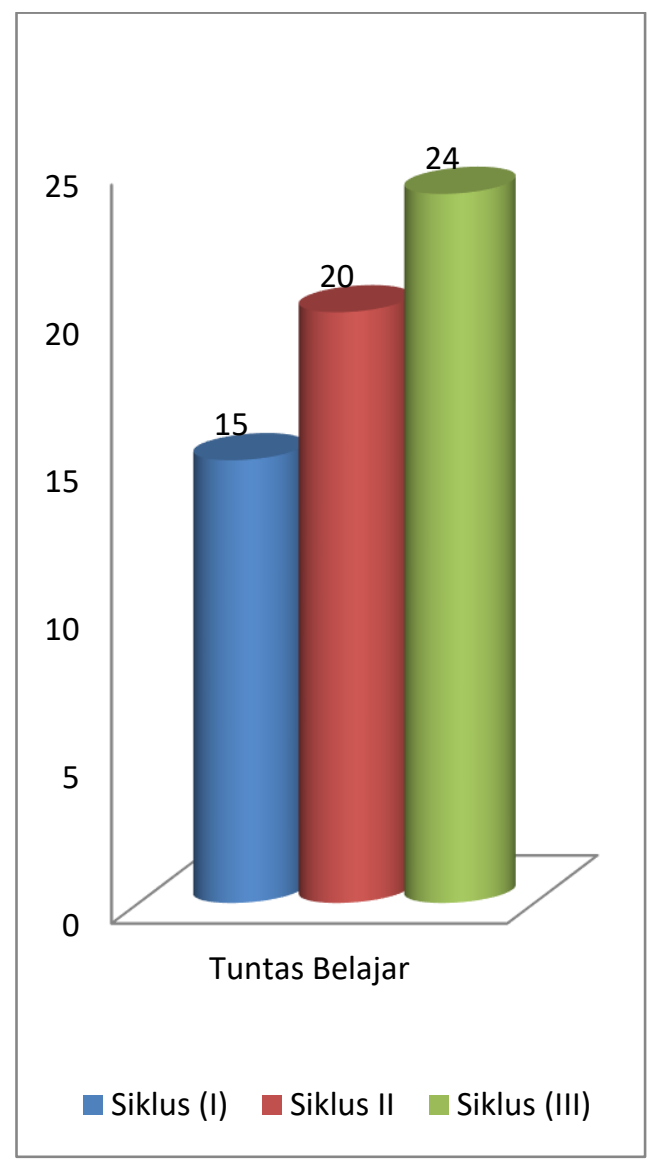

Dari grafik diatas, bisa dilihat terjadi ke-naikan ketuntasan belajar di dari siswa. Dimana pada siklus pertama terdapat 15 siswa atau sekitar $50 \%$ siswa yang telah tuntas merupakan angka yang cukup besar bagi guru IPA. Meskipun belum mencapai $100 \%$ tapi hasil ini sudah membanggakan, mengigat materi pelajaran IPA adalah materi yang rumit dan kurang diminati siswa.

Siswa yang belum tuntas adalah $20 \%$ atau ada 6 siswa yang belum tuntas belajar sesuai KKM. Untuk siswa yang belum tuntas, maka guru tersebut dapat melak-sanakan kegiatan remidial untuk siswa yang belum tuntas. Sedangkan untuk siswa yang sudah tuntas dalam hasil evalusi hasil be-lajar, maka seorang guru masih dapat memberikan materi pengayaaan. Sehingga siswa yang sudah tuntas dan siswa yang be-lum tuntas samasama memiliki tambahan ilmu pengetahuan khususnya pelajaran IPA.

\section{SIMPULAN}

Jadi, bisa disimpulkan dari praktek PTK ini yaitu melakukan kegiatan pembelajaran dengan menggunakan media charta mata pelajaran IPA di MTsN 2 Way Kanan selama 3 siklus dan berdasarkan hasil pembahasan dapat disimpulkan sebagai berikut:

a) Penggunaan media charta dalam pembelajaran dapat meningkatkan hasil 
belajar siswa dalam pengamatan charta

organ tubuh manusia.

b) Media charta memili dampak postif untuk

menaikkan hasil nilai belajar siswa untuk

meningkatkan hasil belajar siswa pada

saat melaksanakan evaluasi pembelajaran.

c) Pendidik perlu kreatif dalam melak-

sanakan pembelajaran dikelas, salah

satunya dapat menggunakan media charta.

\section{DAFTAR RUJUKAN}

Arikunto, S. (2010). Prosedur Penelitian Suatu Pend. Praktik. Jakarta: Rineka Cipta.

Hamalik, O. (2002). Perencanaan Pengajaran. Penerbit :Bumi Aksara. Jakarta

Mahmud, Dimyati.(1990). Proses Belajar Mengajar Siswa. Jakarta. PT Gramedia

Setia, Akbar (2005). Guru Berwajah Ganda. Harian Umum Lampung Post

Sugiyono. (2010). Metode Penelitian Pend. Pendekatan Kuanf, Kual \& R\&D.

Bandung: Alfa Beta.

Wardani I. G. A. K, dkk.( 2006). Penelitian Tindakan Kelas. Jakarta.

Wiriatmadja, Rochiati.(2006). Metode Penelitian Tindakan Kelas Untuk Guru dan Dosen. Bandung. Remaja Rosdakarya. 